\title{
The Competent Management Team as a Condition for Successful Crisis Solving
}

\author{
Drago Dubrovski \\ Faculty of Management, University of Primorska, Koper, Slovenia \\ Email: drago.dubrovski@fm-kp.si
}

Received 19 August 2014; revised 20 September 2014; accepted 12 October 2014

Copyright (C) 2014 by author and Scientific Research Publishing Inc.

This work is licensed under the Creative Commons Attribution International License (CC BY). http://creativecommons.org/licenses/by/4.0/

(c) (i) Open Access

\section{Abstract}

To stop adverse trends and handle the crisis situation on the one hand and to reach turning-point and insure the foundations for new development on the other hand are usually two basic tasks of crisis management when it performs necessary activities in the company in acute crisis. For the successful resolution of a crisis, it is of key importance that the crisis is tackled by managers who along with a desirable knowledge of the company's activities are familiarized with the special characteristics of the crisis management and general creative (intuitive) approach. For their work crisis management will require strategic, as well as fully operational formal and empirical knowledge, possessing at least the minimum amount of knowledge from every business field. Based on the research described in this paper using the sample of selected companies undergoing acute crisis, it is emphasized that from all necessary competences, which crisis team members should possess, the most important thing is the knowledge and experiences from the area of radical restructuring of the company, whereas the familiarisation with the field of operation whose characteristics can soon be mastered by the crisis team members is less important. The financial view of the acute crisis resolution is very important; however, the company cannot further survive if only this area of operation is addressed.

\section{Keywords}

Crisis, Crisis Management, Crisis Team, Competences

\section{Introduction}

All crises create a distressing, uncertain and worrisome situation, which endangers property as well as people, and influences established business and life flows. That is why we want to resolve this situation as soon as possible. Crises in the wider socio-economic environment directly or indirectly affect the position of individual companies or other organizations which may be more or less connected with the broader scope of the crisis. A crisis in one 
sector (e.g. automotive, construction etc.) may have a significant negative impact on the companies from completely different sectors. A crisis can impact any company [1] even if at a certain time when the company is efficient in a fast-growing and, according to all criteria, a high-potential industry, as the crisis can be caused by reasons which are not directly connected to the same industry. The life cycle of a business and the industry in which it operates can be very different. There are countless examples of global companies in domestic and foreign business history, which seem indestructible in their peak but are actually gone today.

A crisis is a short-term undesired, unfavourable and critical situation in a company (organization), directly endangering the existence and further development of this organization and is caused by an intertwined and simultaneous action of both external and internal sources ([2] [3]; cf. also [4]-[19]). As the functioning and behaviour of the company in the state of crisis differs from the one that is present during a period of planned growth, the techniques and methods used by management need to be different. In business practice we are often faced with a dilemma: is it better to appoint as a leading crisis management the person who possesses perfect knowledge of the branch in which a company in acute crisis operates or to give the advantage to the leader who is familiar enough with restructuring projects. The thesis in this article is that the latter can be much more applicable in an acute crisis.

\section{Crisis Elimination}

The results of the crisis can be seen inside the company, as well as in its surroundings. In general, the results of the crisis can be divided into two groups: the downturn of the business performance indicators and the changed behaviour of the parties involved.

Even if the company is operating under normal conditions, natural contradictions exist among expressed interests (e.g. employees and owners, secured creditors and ordinary creditors), which under normal circumstances are well-balanced, and the company pursues the interests of all the participants. In an acute crisis, the balance is disrupted since each participant takes all the measures necessary to protect his own interests that can only be achieved by interfering within the area of interest of another participant. Conflicts of interests thus are aggravated in an acute crisis, and so the different orientation of interests becomes more pronounced. According to their role and position in the company not all participants that share the same interests have the same power or influence. Since specific participants strive to achieve different advantages, their management of interests inside and outside the company also differs.

This knowledge is of key importance for crisis resolution projects which must not be overlooked or underestimated by the crisis management. The pronounced divergence of interests, characteristic of the period of the emergence of a serious (acute) crisis in the company, even more complicates the already complicated internal and external relations of the company. We also have to take into consideration, which is particularly important in the crisis resolution phase, that every interest group has created its own indicators, measures and time frames for estimating the success of the crisis resolution project. The field of balancing divergent interests in order to emphasize their importance is referred to by some as "stakeholder management".

The occurrence of a manageable crisis when there are slim possibilities of keeping or resuscitating the business, bringing negative trends to an end or even beginning a new development cycle, can be referred to as the beginning of the recovery or rehabilitation of the company with the goal to fully eliminate the crisis. The rehabilitation of the company denotes a recovery of the company in crisis with the goal to eliminate the existing unfavourable condition, which poses a threat for the future, to prevent further aggravation of the management and to reestablish the conditions that will enable the company to continue to exist and develop. From the entrepreneurial perspective this is a common notion comprising all business and political, managerial and technical, organisational, financial and other measures that will allow the company to continue to exist and later to operate profitably (cf. [9] [12] [20] and [21]).

\section{Crisis Management}

The management of the rehabilitation process by planning and implementing measures, which ultimately leads to business recovery, is called crisis management (a special part of the strategic management). The reorganization of the existing situation to reestablish normal operations and ultimately the further existence of the company is closely related to the existing crisis, therefore it must be separated from other processes, such as reconstruction, reformation, reorganization, redirection, restructuring, etc. which are not necessarily the result of an acute crisis, 
but are primarily aimed at preventing the crisis from emerging by establishing the further development of the company. Activities of managing a company in acute crisis, the basic tasks of which are: 1) to stop adverse trends and handle the crisis situation (survival); and 2) to reach turning-point (redirectioning) and insure the foundations for new development, are namely crisis management, which also characterizes the performers of these activities. As aforementioned, a company facing a possibility of a rapid winding-up requires a different approach to its managing in comparison with one permitted or possible under normal circumstances of operations. Due to timing and decision making pressure, limited available assets and tendencies towards short-term solutions of operational problems, the crisis manager must use adequate methods and techniques of company and employees leadership. Mastering the crisis situation by itself has no meaning, since the crisis situation is mastered only when the turningpoint of adverse trends has been passed. Only by doing this the company can insure its survival and possibilities to develop.

A recovery process with unfavourable results leads to an unmanageable crisis (the crisis can be defined as unmanageable without initiating the initial rehabilitation procedure). Crisis recovery is a very demanding process and, if we put this into perspective, often involves few chances for success (the deeper the crisis, the less the chances of recovery to be successful are). Many rehabilitation processes prove to be ineffective in the execution phase despite good design and execution. In one of the researches it was established as follows ([22]; see also [23]):

- only $20 \%$ of the companies experiencing significant problems successfully recover;

- as nearly as $33 \%$ of the companies experiencing significant problems are immediately estimated as beyond recovery;

- approximately $50 \%$ of companies which were initially designated as recoverable are actually recovered.

The bigger the crisis, the lesser chances there are for a successful outcome. The level of the successful recovery from an acute crisis is therefore fairly low, which among others on the one hand points to a demanding management of the company in crisis and on the other confirms that there are only few possibilities of a "second chance" in these type of processes ("almost every crisis contains within itself the seeds of success as well as the roots of failure"; [24]). Therefore, choosing the right crisis recovery, particularly choosing (appointing) the crisis team members is of outermost importance. Most organisations rarely undergo a crisis; however, it can lead to a devastating outcome. Efficient crisis management can reduce the damage suffered due to the crisis; however, successful crisis management is very demanding. The crisis, which is pushing organisations into a new and rapidly changing environment, where old individual models of thinking and understating are no longer any use and need to be updated, is one of the factors hindering the response to a crisis [25].

Crisis recovery in a company can only be successful if applied on all business levels of the company and it is therefore essential during recovery (reorganization) to ensure the simultaneous implementation of measures for solving the crisis in two basic areas, namely (cf. [26] and [27]): 1) business (substantive, operative) recovery; and 2) financial recovery. Although a crisis in a company is directly reflected in the financial area (insolvency, deep debts, negative cash flow, etc.), it is actually only the result of developments in other (substantive) areas. Recovery projects are thus frequently focused only on solving financial problems, instead of directing attention to other areas, which are being neglected ("we could solve the crisis with additional financial resources"). For example, financial consolidation alone cannot bring positive results, if the product/service range is outdated, if excessive costs are being generated, if key personnel have left the company, if product quality is questionable etc.

Based on several empirical researches (e.g. [14]) and many actual cases it can be stated that for the successful reorganization of companies with existential problems four essential common conditions generally have to be met:

- a healthy core business, capable of ensuring a positive cash flow and profits, including development or future prospects, based on added value;

- available financial resources (preferably long-term) to overcome liquidity deficits (including the payment of remedial costs) and ensuring development steps (revitalization);

- a positive attitude and sufficient motivation of the employees for the reorganization process;

- a capable, competent management team with the necessary authorizations (without which even the best projects are bound to fail).

Regardless of the programmes, marketing opportunities, financial incentives, non-refundable funds, "government contracts", etc., it will be unsuccessful if not tackled by suitable or qualified people who have the necessary know-how to usefully exploit them. When identifying the sources of the crisis, as well as the sources for 
crisis elimination and prevention, the competent management is a prima et ultima ratio. The company's management can eliminate most internal sources of the crisis or prevent their action and effectively adapt to external changes or, in the event of increased power, influence such changes.

\section{Crisis Management Team}

Crisis management comprises planning, organizing, directing and monitoring companies (organizations) experiencing difficulties that directly endanger their existence and further development and its purpose is to stop negative trends by achieving a drastic change and providing the foundation for redevelopment. In crisis management, the leading manager rarely involves a person who was already working at the company during the period that led to the acute crisis. Therefore, the company almost as a rule engages external managers, experts and consultants to tackle the crisis. However, the overall crisis team usually covers external and internal members.

The crisis manager who assumes the role of crisis resolution within a company does not enter into a full-time employment agreement for an indefinite period of time, but acts according to the principle of the so-called interim management that can designate hiring an individual or an entire team for a definite period of time (interim executive management; Ger. Interimsmanagement, Sanierungspraktiker). Which functions, along with the managerial, will this interim management assume, will depend on the availability of adequate experts and managers in the company and the most deficient functions.

The crisis management team can in principle consist of one or more members. In view of the above, [28] defined four models: a team-oriented project group (high level of decentralised decisions, many members); management support (higher level of decentralised decisions, more members); a crisis board (lower level of decentralised decisions, few members); individual (low level of decentralised decisions). An overview of Müller's four models draws our attention to the vast selection of possibilities for the formation of a crisis management team; whereby, the actual selection in the given event will depend on a number of factors, with the availability of managers with the necessary competencies having the key role. According to [29] the formation of a crisis team must be done by distinguishing between the measures and conditions which the team members must fulfil. According to [30] such measures must also include the power (authority) and the ability of impartial, neutral insight.

For practical purposes, the findings established by [31] state that the crisis team should consist of members having the following work styles: the "ideas" person (a person constantly contributing new ideas and suggestions); the communicator (a person who facilitates the communication flow within and outside of the team); the doom merchant (a "devil's advocate" challenging the proposed ideas and solutions); the bookkeeper (a person who makes detailed notes and strives for perfection); the humanist (a person who always points out the human factor in the problems).

For professional specializations [32] suggest the following ideal members of the crisis team: current affairs manager, expert from the applicable company's field of operation, financial specialist, legal advisor, and restructuring expert.

[33] draws attention to the following six rules of team work in crisis management, which must be strictly followed:

- his individual area of responsibility, every member of a top management team has the last word, speaks for the whole team, and commits the whole team,

- no one is to make a decision in someone else's area of responsibility,

- outside the team, no judgement is to be passed on any team member,

- a team is not a committee, therefore it needs a leader, a chairman, who must have the casting vote,

- certain decisions must be made by the team as a whole,

- every team member is duty-bound to keep all the other members informed of everything occurring in his area of responsibility.

In concrete situations it will be difficult to form a perfect crisis team, since good experts are usually constantly engaged in different current projects, and the timing of their availability is not synchronized.

For the successful resolution of a crisis it is of key importance that the crisis is tackled by managers which along with a desirable knowledge of the company's activities are familiarized with the special characteristics of the crisis management and general creative (intuitive) approach, because there are few opportunities to learn during a crisis, if any. For their work crisis management will require strategic, as well as fully operational formal and empirical knowledge, possessing at least the minimum amount of knowledge from every business field (e.g. 
financial, accounting, human resources, information, production, commercial, marketing, legal function, etc.). For the crisis management project to be successful, key competencies possessed by the expert are required. In view of the complexity of the management of a company undergoing serious difficulties, crisis management is therefore denoted as a "composite" discipline, because a multi-disciplinary approach to problem solving is required in order to achieve the objectives of managing a company undergoing a crisis.

All general competencies (e.g. [34]) should also apply to crisis management; however, some special knowledge and skills are more important. The special competencies that should be possessed by a perfect crisis manager along with general professional, methodological, social, personal and executive knowledge, expertise and skills are as follows ([35], cf. also [13] [27] and [36]):

- a business sense with professional management skills, confrontational skills and the ability to cope under extraordinary circumstances with a clear understanding of the situation he/she is dealing with;

- a broad business experience and experience with rehabilitation projects for heuristic and empirical decision making;

- knowledge he/she may employ in judging the possible reaction of individual participants of the organisation or interest groups and estimates the results after the rehabilitation process (knowing that it could be foreseen);

- skills and experience with local and international negotiations, particularly in extraordinary conditions;

- readiness to assume the function of moderator or mediator;

- expert communication skills.

The engagement of a crisis management team can be initiated by the company itself (existing management or supervisory body), but can also be initiated by the creditors (e.g. banks or state supervisory bodies) who can demand the appointment of the so-called compulsory administration. The external management or consultants can on account of previous experience with similar events quickly identify the causes and propose measures accordingly, and since they possess the knowledge and professional know-how they can provide an unbiased insight into the internal conflicts, thus raising the necessary trust of the banks, since many companies have a very damaged relationship with the banks, and similar.

The crisis manager cannot only carry out a consultancy function (act as a consultant), but must carry out an executive or decision-making function (act as a decision maker) otherwise the measures decided on cannot be fully implemented. Such a manager must have a strong, strict and quick character, since he usually assumes such a function only for the duration of the crisis and the turnaround of the negative trends. Many managers are only successful in crisis, critical and stressful situations; while they are neither interested nor attracted by further development and so they search for new opportunities. In addition a specific management approach that has proved to be successful in one specific phase can be totally unsuccessful for another phase. Few managers successfully manage the company in the rehabilitation phase or crisis elimination phase as well as in the phase of further development of a company.

For crisis management, which is broader concept than just risk management, it is characterized by the aggravated conflicts of interests, so the different orientations of interests become more pronounced. The pronounced divergence of interests, characteristic of the period of the emergence of a serious (acute) crisis in the company, even more complicates the already complicated internal and external relations of the company. The field of balancing divergent interests or "stakeholder management" must be a consistent part of crisis management when not only exceptional well-known general but also special competencies of management are needed.

\section{Empirical Evidence}

In order to establish who are the members that participate in the crisis management teams involved in the projects of acute crisis rehabilitation, twelve Slovenian companies were selected in which the author assumed different active roles in the years from 2000 to 2012, which allowed him not only to analyse quantitative data, but also gave him a (qualitative) insight into the crisis creation process or its elimination or rehabilitation. Only those companies were selected in which the acute crisis was successfully eliminated, so that they continue to operate (successful crisis elimination), even though under different forms of organisation.

The crisis management team composition in the sample of aforementioned companies is shown in Table 1.

The aforementioned overview suggests that one of the crisis team members was always (100\%) a restructuring expert (crisis manager, transformation leader), often a financial expert (67\%) and in a half of the cases a marketing \& sales expert (50\%), while an expert from the applicable company's field of operation was included 
Table 1. The crisis management team composition in the selected cases.

\begin{tabular}{|c|c|c|c|c|c|c|c|c|c|c|}
\hline Case & Branch/industry & $\begin{array}{c}\text { No. of } \\
\text { employees }\end{array}$ & $\begin{array}{c}\text { Financial } \\
\text { expert }\end{array}$ & $\begin{array}{l}\text { Marketing \& } \\
\text { sales expert }\end{array}$ & $\begin{array}{l}\text { Production, } \\
\text { R \& D expert }\end{array}$ & $\begin{array}{l}\text { Legal } \\
\text { expert }\end{array}$ & $\begin{array}{c}\text { HR } \\
\text { expert }\end{array}$ & $\begin{array}{l}\text { Branch } \\
\text { expert }\end{array}$ & $\begin{array}{l}\text { International } \\
\text { expert }\end{array}$ & $\begin{array}{c}\text { Restructuring } \\
\text { expert }\end{array}$ \\
\hline 1 & $\begin{array}{l}\text { Furniture } \\
\text { production }\end{array}$ & 580 & + & + & & + & & + & & + \\
\hline 2 & General retail & 530 & + & + & & & + & + & & + \\
\hline 3 & Textile production & 520 & + & + & & & & & + & + \\
\hline 4 & Construction & 450 & + & & + & & & & & + \\
\hline 5 & Glass production & 380 & + & & & & & & & + \\
\hline 6 & Textile production & 380 & & + & & & & + & & + \\
\hline 7 & Food processing & 320 & + & & & & & + & & + \\
\hline 8 & $\begin{array}{l}\text { Export-import } \\
\text { trading }\end{array}$ & 290 & & & & + & & & + & + \\
\hline 9 & $\begin{array}{l}\text { Agricultural } \\
\text { cooperative }\end{array}$ & 260 & + & + & + & & & + & & + \\
\hline 10 & Food retail & 160 & & + & & & & & & + \\
\hline 11 & Metal processing & 150 & & & + & & & & + & + \\
\hline 12 & $\begin{array}{c}\text { Metal } \\
\text { maintenance }\end{array}$ & 130 & + & & & & & & & + \\
\hline
\end{tabular}

only in five cases (42\%). Certainly, the composition of the particular team is based also on the characteristics of the branch and the problems the crisis team must deal with. Based on the sample of selected companies undergoing acute crisis, in the hypothesis stating the necessary competences, which crisis team members should possess, the most important is the radical restructuring of the company, whereas the familiarisation with the field of operation whose characteristics can soon be mastered by the crisis team members is less important. The financial view of the acute crisis resolution is very important; however, the company cannot further survive if only this area of operation is addressed.

The research has numerous weak spots, which predominantly include the small number of selected case studies; however, it draws attention to key knowledge or areas of expertise, which crisis team members should possess. The familiarisation with the field of operation was not a key factor in the companies under investigation, whereas the familiarisation with the projects of radical changes (in structures, systems, strategies, business models, processes) can be a key factor for successful survival and renewal of the company in an acute crisis. According to the author's own many years' strategic management and restructuring consultancy practice companies in an acute crisis in most cases attempt to solve the acute crisis with various forms of financial restructuring, meaning that they are actually dealing with the consequences rather than the causes of the crisis, which have brought on the need for financial disburdening and pay surprisingly little attention to the changes of their ineffective business models (that led to the acute crisis) and introducing new strategies, structures, processes and systems, even though in this case this is the most important area of renewal, which will ensure further existence and development ("there has never been as much interest in business models as there is today" [37]). As mentioned earlier crisis recovery cannot be successful if it is not applied simultaneously in business (substantive) and financial areas. Only from financial restructuring a distress company cannot ensure its further existence and development.

\section{Conclusions}

For the successful reorganization of companies with existential problems, four essential common conditions generally have to be met (a healthy core business; available financial resources; a positive attitude and sufficient motivation of the employees for the reorganization process; a capable, competent management team). In this article we have focused on the last one.

Based on several empirical researches, including the research described in this paper, it is emphasized that for the successful resolution of a crisis it is of key importance that the crisis is tackled by managers who are familiar 
with the special characteristics of the crisis management and restructuring projects. Despite the fact that for their work crisis management will require strategic, as well as fully operational formal and empirical knowledge, possessing at least the minimum amount of knowledge from every business field, the most important competencies can derive from the experts for restructuring projects rather than from those knowing the branch in which the company in acute crisis operates (certainly, it can be a great advantage).

The assessment of the individual competencies possessed by crisis team members to successfully resolve the crisis or rehabilitate the company, which can change on a case-by-case basis, has to be taken into consideration by those who are responsible for the appointment of the crisis manager and creation of the crisis team as one of the four key conditions for ensuring the survival and development of the company's undergoing difficulties.

\section{References}

[1] Crandall, W.R. and Mensah, E.C. (2008) Crisis Management and Sustainable Development: A Framework and Proposed Research Agenda. International Journal of Sustainable Strategic Management, 1, 16-24. http://dx.doi.org/10.1504/IJSSM.2008.018124

[2] Dubrovski, D. (2004) Peculiarities of Managing a Company in Crisis. Total Quality Management \& Business Excellence, 15, 1199-1207. http://dx.doi.org/10.1080/1478336042000255578

[3] Dubrovski, D. (2011) Razsežnosti kriznega managementa. Mednarodna fakulteta za družbene in poslovne študije, Celje.

[4] Apaslan, C.M. and Mitroff, I.I. (2011) Swans, Swine, and Swindlers. University Press, Stanford.

[5] Barnett, C.K. and Pratt, M.G. (2000) From Threat-Rigidity to Flexibility: Toward a Learning Model of Autogenic Crisis in Organizations, Journal of Organizational Change Management, 13, 74-88. http://dx.doi.org/10.1108/09534810010310258

[6] Barton, L. (1993) Crisis in Organizations. South-Western College Publishing, Cincinnati.

[7] Crone, A. (2007) Die Unternehmenskrise. In: Crone, A. and Werner H., Eds., Handbuch Modernes Sanierungs Management, Franz Vahlen, München.

[8] Fink, S. (1986) Crisis Management. Amacom, New York.

[9] Grünert, T. (2007) Mergers \& Acquisitions in Unternehmungskrisen. Deutscher Universitäts-Verlag, Wiesbaden.

[10] Heath, R. (1998) Crisis Management for Managers and Executives. Financial Times, Pitman Publishing, London.

[11] Hermann, C.F. (2008) Some Consequences of Crisis Which Limit the Viability of Organizations. In: Boin, A., Ed., Crisis Management, Sage, Los Angeles, 210-224.

[12] Homel, U., Knecht, T.C. and Wohlenberg, H. (2006) Sanierung der betrieblichen Unternehmenskrise. In: Homel, U., Knecht, T.H. and Wohlenberg, H., Eds., Handbuch Unternehmensrestrukturierung, Gabler Verlag, Wiesbaden, 27-60. http://dx.doi.org/10.1007/978-3-8349-9149-2 1

[13] James, E.H. and Wooten, L.P. (2010) Leading Under Pressure. Routledge, New York.

[14] Kraus, G. and Becker-Kolle, C. (2004) Führen in Krisenzeiten. Gabler, Wiesbaden. http://dx.doi.org/10.1007/978-3-322-84535-1

[15] Lalonde, C. (2008) Organiser la réponse a la crise. L’Harmattan, Paris.

[16] Lerbinger, O. (1997) The Crisis Manager. Lawrence Erlbaum Associates, Mahwah.

[17] Neubauer, M. (1999) Krisenmanagement in Projekten. Springer, Berlin. http://dx.doi.org/10.1007/978-3-662-08223-2

[18] Roux-Dufort, C. (2003) Gérer et décider en situation de crise. Dunod, Paris.

[19] Slatter, S. (1987) Corporate Recovery. A Guide to Turnaround Management. Penguin Books, London.

[20] Andersch, T. and Schneider, K.J. (2006) Erstellung und Testierung von Sanierungskonzepten. In: Hommel, U., Knecht, T.C. and Wohlenberg, H., Eds., Handbuch Unternehmensrestrukturierung. Gabler Verlag, Wiesbaden, 303-334.

[21] Harz, M., Hub, H.-G. and Schlarb, E. (2006) Sanierungs-Management. Wirtschaft und Finanzen, Stuttgart.

[22] Platt, H.D. (1998) Principles of Corporate Renewal. The University of Michigan Press, Ann Arbor.

[23] Slatter, S., Lovett, D. and Barlow, L. (2006) Leading Corporate Turnaround. Jossey-Bass, Chichester.

[24] Augustine, N.R. (2000) Managing the Crisis You Tried to Prevent. In: Harvard Business Review on Crisis Management, Harvard Business School Press, Boston, 1-31.

[25] Roberts, K.H., Madsen, P. and Desai, V. (2007) Organizational Sensemaking during Crisis. In: Pearson, C.M., Roux-Dufort, C. and Clair, J.A., Eds., International Handbook of Organizational Crisis Management, Sage Publications, 
Los Angeles, 109-122. http://dx.doi.org/10.4135/9781412982757.n4

[26] Kraus, K.-J. and Gless, S.E. (2004) Unternehmensrestrukturierung/-sanierung und strategische Neuausrichtung. In: Buth, A.K. and Hermanns, M., Eds. Restrukturierung, Sanierung, Insolvenz, Verlag C.H. Beck, München, 109-132.

[27] Seefelder, G. (2007) Unternehmenssanierung. Schäffer-Poeschel, Stuttgart.

[28] Müller, R. (1986) Krisenmanagement in der Unternehmung. Peter Lang, Frankfurt am Main.

[29] Faulhaber, P. and Landwehr, N. (2005) Turnaround-Management in der Praxis. Campus, Frankfurt.

[30] Meyers, G.C. and Holusha, J. (1986) Managing Crisis. Unwin, London.

[31] Regester, M. (1987) Crisis Management. Hutchinson Business, London.

[32] Williams, D.R. and Roy, S.N. (1999) Merger and Acquisition Strategies for the Distressed Company. In: Di Napoli, D., Ed., Workouts \& Turnarounds 2: Global Restructuring Strategies for the Next Century, John Wiley \& Sons, New York, 424-437.

[33] Malik, F. (2006) Effective Top Management. Wiley-VCH, Weinheim.

[34] Lang-von-Wins, T., Kaschube, J. and von Rosenstiel, L. (2006) Führungskompetenzen bei der Unternehmensrestrukturierung. In: Homel, U., Knecht, T.H. and Wohlenberg, H., Eds., Handbuch Unternehmensrestrukturierung, Gabler Verlag, Wiesbaden, 253-276.

[35] Dubrovski, D. (2011) Additional Knowledge Needed in Crisis Management. In: Dermol, V., Ed. Knowledge as Business Opportunity: Proceedings of the Management, Knowledge and Learning International Conference 2011, 22-24 June 2011, Celje, Slovenia, International School for Social and Business Studies, Celje, 159-166.

[36] Bibeault, D.B. (1999) Corporate Turnaround: How Managers Turn Losers into Winners. Beard Books, Washington.

[37] Casadesus-Masanell, R. and Ricart, J.E. (2011) How to Design a Winning Business Model. Harvard Business Review, 89, 101-107. 
Scientific Research Publishing (SCIRP) is one of the largest Open Access journal publishers. It is currently publishing more than 200 open access, online, peer-reviewed journals covering a wide range of academic disciplines. SCIRP serves the worldwide academic communities and contributes to the progress and application of science with its publication.

Other selected journals from SCIRP are listed as below. Submit your manuscript to us via either submit@scirp.org or Online Submission Portal.
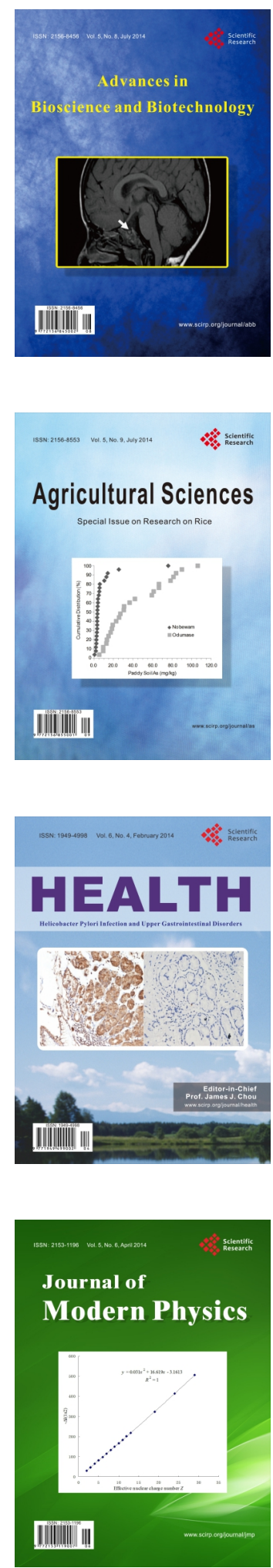
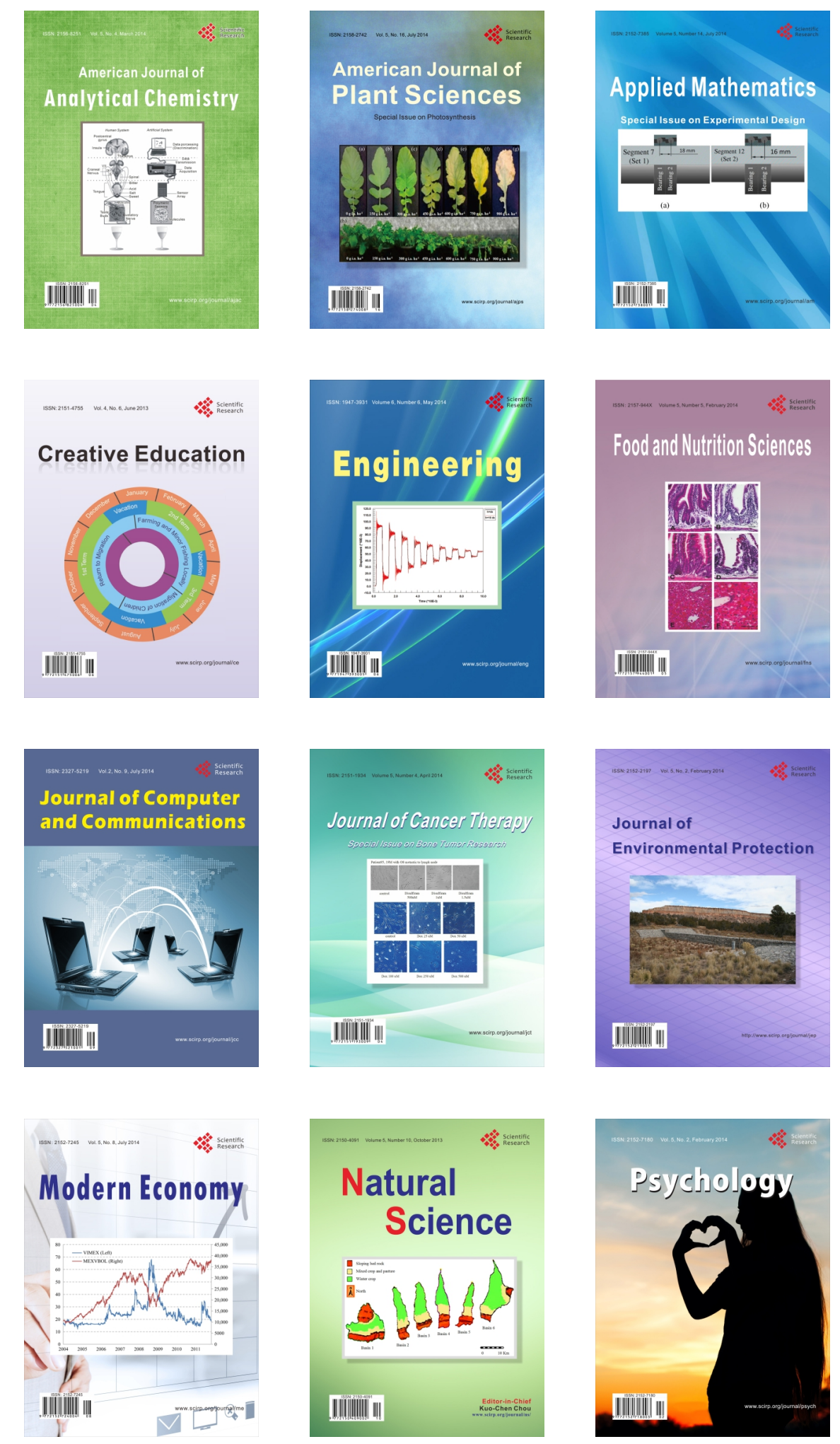